\title{
THE INCIDENCE OF WHEAT CROWN ROT DEPENDING ON AGRONOMIC PRACTICES
}

\author{
Laura Paulovska ${ }^{1,2}$, Biruta Bankina ${ }^{1}$, Ance Roga $^{3}$, Dāvids Fridmanis ${ }^{3}$ \\ ${ }^{1}$ Latvia University of Agriculture \\ 2'Agrokimija Saldus' SIA/Ltd, Latvia \\ ${ }^{3}$ Latvian Biomedical Research and Study Centre \\ paulovska.laura@gmail.com
}

\begin{abstract}
Wheat crown rot is a harmful disease that can be caused by different pathogens. The control of this disease is complicated because of the diversity of pathogens and an insufficient efficacy of fungicides; therefore, the agronomic practices of wheat production are an important tool for reducing the disease development. The aim of this study was to estimate the incidence of wheat crown rot depending on soil tillage system and on the pre-crop of wheat in the year 2016. The field experiment was carried out at the Research and Study farm 'Peterlauki' of the Latvia University of Agriculture in the autumn of 2008. The data obtained in 2016 are analyzed in this study: A - soil tillage system: 1 - traditional soil tillage with ploughing at the depth of $22-24 \mathrm{~cm}, 2$ - reduced soil tillage with disc harrowing up to the depth of $10 \mathrm{~cm}$; B - pre-crop of winter wheat: 1 - wheat, 2 - oilseed rape, 3 - faba beans. The incidence of crown rot was not influenced by soil tillage system, but the impact of pre-crop was significant $(p=0.006)$. The level of disease was essentially higher in continuous wheat sowings. The experiments showed that the main causal agents of the disease were Fusarium spp. and Oculimacula spp. The spectrum of pathogens was not dependent on a particular agronomic practice.
\end{abstract}

Key words: soil tillage, crop rotation, Fusarium, Oculimacula, Microdochium, Phaerosphaeria pontiformis.

\section{Introduction}

Winter wheat (Triticum aestivum L.) is one of the most cultivated and economically beneficial crops in Latvia. In 2015, wheat sowings occupied 38\% out of the total field crop area (CSP, 2016). The increasing proportion of wheat in the cropping systems may increase the pressure of diseases, including stem base and root rot (Jenkyn et al., 2010; Winter, Mol, \& Tiedemann, 2014).

Wheat stem base (crown) rot is a widespread and harmful disease, which can cause significant yield losses, especially under the conditions of intensive wheat production. The efficacy of fungicide application does not provide a sufficient control because the disease can be caused by different causal agents with different sensitivities to fungicides; therefore, it is important to understand the impact of a particular agronomic practice on the development of this disease. Several names for this disease can be found in the literature depending on the disease symptoms and its causal agent. The most frequently used names of the disease are: eyespot caused by Oculimacula spp., Fusarium foot rot caused by Fusarium spp., brown foot rot caused by Microdochium nivale, takeall disease caused by Gaeumannomyces graminis, and sharp eyespot caused by Rhizoctonia cerealis (Crous, Groenewald, \& Gams, 2003; Bateman et al., 2007; Jenkyn, Gutteridge, \& White, 2014; Winter, Mol, \& Tiedemann, 2014; Matušinsky et al., 2016; Weber et al., 2016). Precise identification of the disease is complicated under field conditions (Polley \& Turner, 1995). Complex infection of the same stem base by two or three pathogens has been proved by Matusinsky
(Matusinsky et al., 2008). For these reasons, the general name 'crown rot' is used in this study.

The impact of different soil tillage systems and crop rotations on the development of crown rot has been investigated for many years worldwide, but the results obtained are still contradictory - they depend on the meteorological and climatic conditions in a particular region and, at the same time, can also be influenced by the spectrum of wheat crown rot pathogens.

Three-year studies in Poland revealed a distinctive impact of soil tillage systems depending on the pathogens; conventional ploughing did not decrease the level of Oculimacula spp. and Fusarium spp., but essentially reduced the level of G. graminis (Majchrzak et al., 2016). Conservation tillage systems promote the increase in Fusarium infection in general; however, this effectiveness was dependent on Fusarium species because the survival of chlamydospores that are produced by $F$. culmorum was not influenced by the soil tillage method (Moya-Elizondo, 2013).

Crop rotation has been described as the most effective agrotechnical method to reduce the severity of crown rot, including the diseases caused by Fusarium spp. The disease can be caused by different Fusarium species with different abilities to survive without hosts, and a number of species can infect other grass species (Moya-Elizondo, 2013). The pre-crop significantly influences the development of wheat crown rot; however, this impact depends on a particular pathogen. The level of take-all has been essentially higher in continuous wheat sowings compared to other crops; maize as the pre-crop has not influenced the occurrence of Fusarium spp., but the 
results related to eyespot have not been clear (Wenda et al., 2016).

Previous studies in Latvia (Bankina et al., 2013) showed that agrometeorological conditions of year are the most important factor influencing the incidence of crown rot; however, also agronomic methods are important. The incidence of crown rot in continuous wheat sowings was $10 \%$ higher than in the wheat fields following winter or spring oilseed rape. The impact of soil tillage system is not so clear - ploughing only slightly decreased the level of disease compared to reduced tillage.

The aim of this study was to estimate the incidence of wheat crown rot depending on soil tillage system and on the pre-crop of wheat in the year 2016 and to identify causal agents of disease.

\section{Materials and Methods}

\section{Sites and experimental design}

The field experiment was carried out at the Research and Study farm 'Peterlauki' of the Latvia University of Agriculture (central part of Latvia $-56^{\circ}$ $30.658^{\prime} \mathrm{N}$ and $23^{\circ} 41.580^{\prime} \mathrm{E}$ ) in the autumn of 2008 . The total area of the experimental field was 6 ha, the size of each plot -0.25 ha. Different aspects related to soil properties and plant growth were investigated in this trial, and the evaluation of the development of wheat crown rot depending on agronomic practices was only one part of the observations.

Field trials were designed as a two-factorial experiment: soil tillage methods, and crop rotation. The data obtained in 2016 were analyzed: A - soil tillage system: 1 - traditional soil tillage with ploughing at the depth of $22-24 \mathrm{~cm}$ (TT), 2 - reduced soil tillage with disc harrowing up to the depth of $10 \mathrm{~cm}$ (RT); B - pre-crop of winter wheat: 1 - wheat (W), 2 - oilseed rape (OR), 3 - faba beans (FB).

The soil type was Cambic Calcisol, silty clay loam, neutral ( $\mathrm{pH}$ 7.3), with high content of phosphorus and potassium (148 and $295 \mathrm{mg} \mathrm{kg}^{-1}$ respectively) consequently, the soil was suitable to winter wheat production. All agronomic measures were applied uniformly, according to the requirements of agronomic practices under the conditions of intensive wheat production. Seeds were treated (fludioxonil, $75 \mathrm{~g} \mathrm{~L}^{-1}$, cyproconazole, $25 \mathrm{~g} \mathrm{~L}^{-1}$, dose $\left.1.5 \mathrm{~L} \mathrm{t}^{-1}\right)$, but fungicides against stem base diseases were not applied.

\section{The assessment of crown rot and the identification of causal agents}

The incidence of wheat crown rot was evaluated shortly before harvesting. Plants were collected from two adjacent rows (each $10 \mathrm{~cm}$ long) in five randomly chosen places of each plot (altogether 12 wheat plots), approximately 300 stems. Crown rot was determined visually, and the incidence of disease was calculated.

From each plot, a total of 100 randomly chosen stems with the symptoms of wheat crown rot were prepared for identification of the disease causal agents. Small parts of infected wheat stems (approximately $2 \mathrm{~mm}$ long) were superficially sterilized with $1 \%$ sodium hypochlorite for $3 \mathrm{~min}$, rinsed three times in sterile distilled water, and placed onto potato-dextrose agar (PDA) enriched with streptomycin and penicillin to avoid bacterial infection. Plates were incubated at $+20{ }^{\circ} \mathrm{C}$ for $7-10$ days. Fungi were preliminary

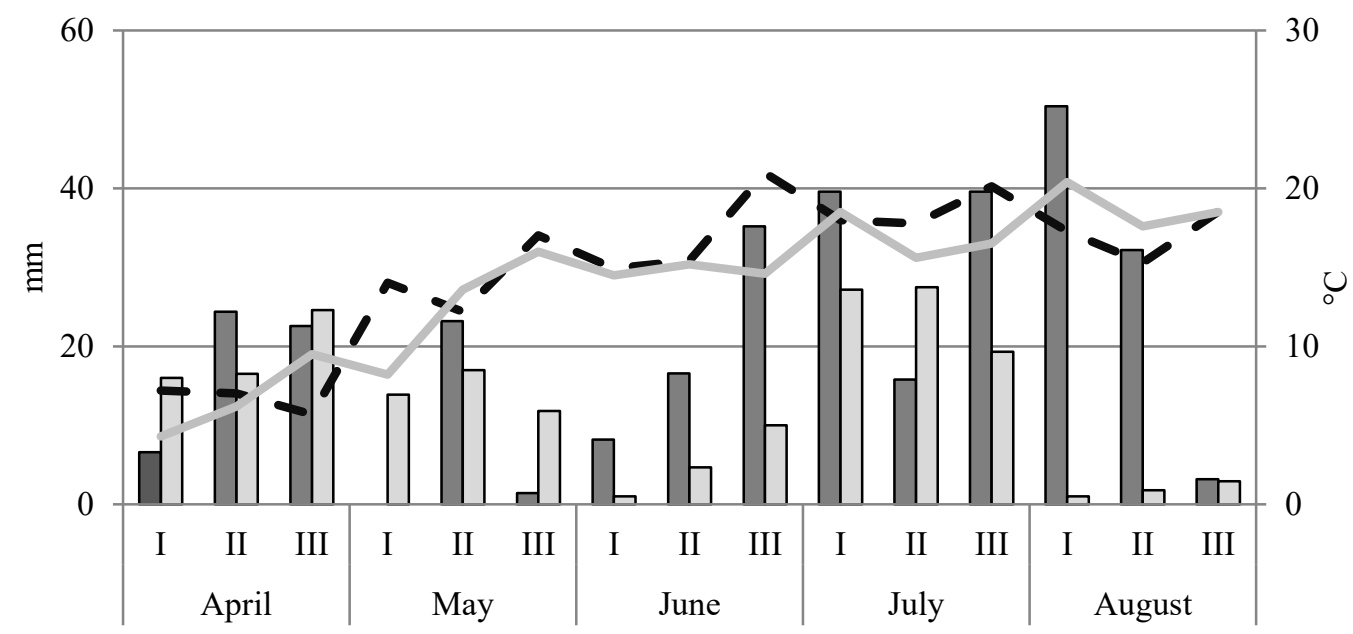

$$
\begin{aligned}
& \square \text { Precipitation in } 2016, \mathrm{~mm} \sqsubset \text { Long-term average, } \mathrm{mm} \\
& - \text { Temperature in } 2016,{ }^{\circ} \mathrm{C} \rightleftharpoons \text { Long-term average, }{ }^{\circ} \mathrm{C}
\end{aligned}
$$

Figure 1. The average temperature and the amount of precipitation in 2016, and the long-term average data. 
identified both directly on the isolation plates (by the colour and texture of mycelium and the pigmentation of media) and microscopically (by morphological characteristics of conidia and conidiophores).

The results of identification were confirmed by the molecular genetic analyses. All obtained isolates were grouped according to the similarity of morphological peculiarities, and two examples of each group were prepared for molecular genetic analyses. The identification of fungal isolates on genus level was performed through isolation of genomic DNA from $10 \mu \mathrm{g}$ of fungal material, sequencing of the ribosomal RNA gene Internal transcribed spacer (ITS) region and subsequent BLAST analysis of acquired sequences against NCBI nucleotide database. All molecular biology related activities were carried out at 'Genome center'- a genetic analysis core facility of Latvian Biomedical Research and Study center.

\section{Meteorological conditions}

The meteorological data in 2016 were collected from a meteorological station closely located to the trial site. The long-term meteorological data were collected from the nearest hydro-meteorological station (HMS) 'Latvian Environment, Geology and Meteorology Centre', Dobele HMS (Fig. 1).

The meteorological conditions in 2016 were suitable for wheat production, and temperature during the period of vegetation was similar to the long-term average. Higher amounts of precipitation during wheat stem elongation and ripening may have promoted the development of wheat crown rot.

\section{Data analysis}

The data of wheat crown rot incidence were statistically processed by the computer program
'R Studio'. The analysis of variance ANOVA was used to analyze the effects of the variables of wheat crown rot incidence. The general linear model was used to evaluate the impact of the factors that had influenced the incidence of wheat crown rot. The general linear model included the soil tillage (traditional or reduced) and the pre-crop (wheat, oilseed rape, faba been). Pairwise comparisons between factor levels were done using the Bonferroni test; the level of significance was $\alpha=0.05$.

\section{Results and Discussion}

The level of wheat crown rot in 2016 was relatively high - the average incidence was $68 \%$, which is in accordance with the findings of other scientists, for example, Moya-Elizondo et al. (2015) reported that incidence of crown rot achieved $72 \%$. Meteorological conditions in 2016 were similar to long-term average data and were favourable for the development of diseases, including crown rot.

Soil tillage method did not influence the level of wheat crown rot in our experiments, which is contrary to other investigations. Several papers have reported on the possibility of reducing the disease by ploughing, which interrupts the life cycles of pathogens; however, most of the researchers have noted that it depends on the biological peculiarities of pathogens, for example, ploughing decreased the level of eyespot on triticale in Lithuania (Janusauskaite \& Ciuberkis, 2010), but in other investigations, the efficacy of ploughing was dependent on the causal agents of the disease (Majchrzak et al., 2016). Váňová et al. (2011) suggest that conventional ploughing does not decrease the level of eyespot because of the undecomposed infected plant residues that could be brought on the topsoil level. Previous investigations in

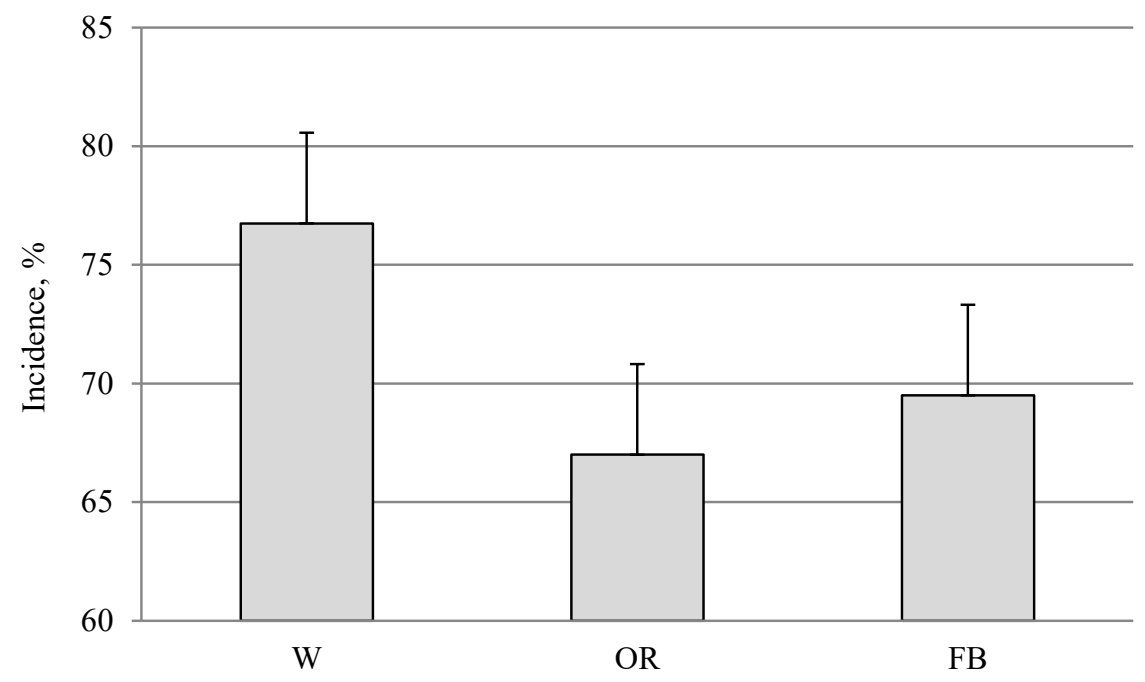

Figure 2. The incidence of the wheat crown rot depending on pre-crop: $\mathrm{W}$ - wheat; OR - oilseed rape; FB - faba beans. 


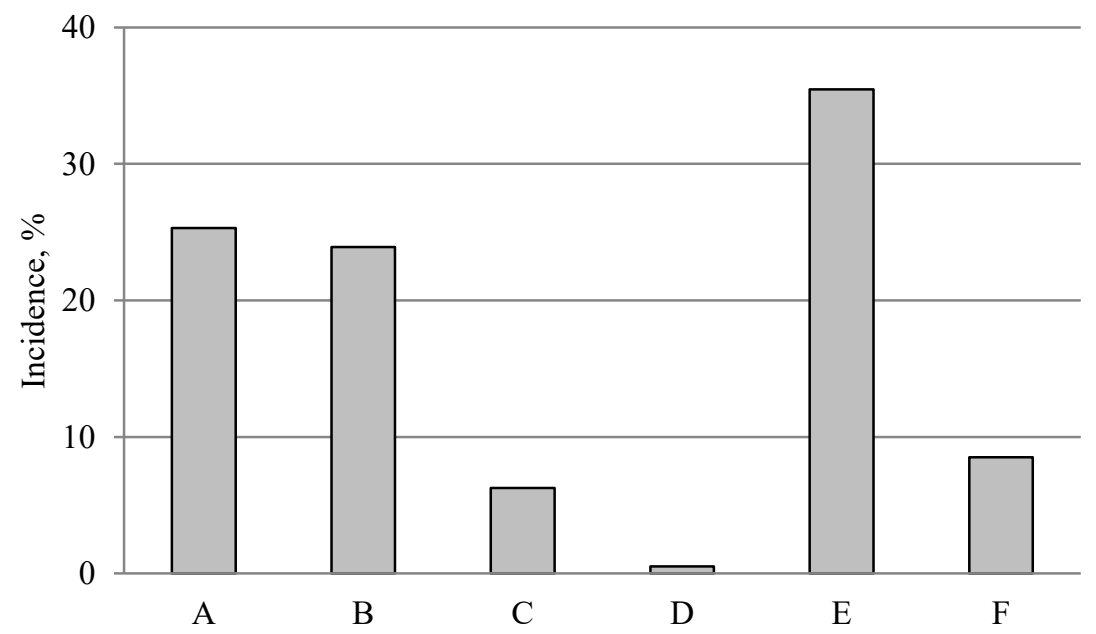

Figure 3. The incidence of pathogens isolated from symptomatic wheat stem bases:

A - Oculimacula spp; B - Fusarium spp.; C - Microdochium nivale/majus; D - Microdochium bolleyi; E-Phaeosphaeria; and F - others.

Latvia have not recognized ploughing as an important tool to reduce the risk of this disease (Bankina et al., 2013).

Crop rotation has been described as the most effective agrotechnical method to reduce the severity of crown rot. The findings of this study confirm the importance of the pre-crop of wheat to the development of crown rot (Fig. 2).

The incidence of crown rot was significantly higher in continuous wheat sowings $(p=0.006)$, whereas oilseed rape and faba beans decreased the level of this disease; however, an essential difference between these two pre-crops was not determined. Precise identification of pathogens is essentially necessary to explain the obtained results, because influence of precrop is depending on pathogens' spectrum.

Of the 1150 isolates obtained from the infected wheat stems in 2016, 56\% were the causal agents of wheat crown rot (Oculimacula spp., Fusarium spp. and Microdochium spp. together), 9\% were different saprotrophic fungi, and 35\% were identified as Phaeosphaeria pontiformis (Fig. 3). Agronomic practices did not influence the proportions of different fungal species isolated from the wheat steams.

Stem crown rot was caused mainly by Oculimacula spp. (45\%) and Fusarium spp. (43\%). Microdochium spp. was found in $11 \%$ of isolates, of which $1 \%$ of isolates were identified as Microdochium bolleyi. These are unexpected results, because during previous investigations pathogens form Microdochium spp. were not found in this trial site (Bankina et al., 2013). Such widespread pathogens as Gaeumannomyces graminis and Bipolaris sorokiniana were not found, although these pathogens were found only occasionally in previous investigations. Such spectrum of pathogens could be explained by soil characteristics, for example, G. graminis prefers light, poorer soils than those on the experimental site. The spectrum of pathogens detected in one year, of course, does not allow drawing complete conclusions, but it is possible to make a hypothesis that Fusarium spp. and Oculimacula spp. are the main pathogens involved in the development of crown rot. These results confirm the other data obtained by several scientists (Gala et al., 2014; Matušinsky et al., 2016; Wenda-Piesik et al., 2016).

The importance of Microdochium spp. has been detected by several authors in the last ten years (Matusinsky et al., 2008, 2016; Ren et al., 2015). Although this pathogen is usually described as the causal agent of snow mould (Bankina et al., 2012) and seedling blight, our results highlight the significance of this pathogen on the fungal complex associated with crown rot. M. nivale and M. majus have been found with similar frequency in the seeds and seedlings in Lithuania (Jonavičiene et al., 2016), but in our experiments, these two species have not been identified yet. $M$. bolleyi has been rarely recognized as a wheat pathogen (Vujanovic, Mavragani, \& Hamel, 2012); this fungus is usually considered as a saprotroph, and further studies are needed to clarify its life cycle and impact on wheat.

$P$. pontiformis is an endophyte in wheat, but the role of this fungus is unclear. Similar results have been obtained in Chile, where the isolation frequency of $P$. pontiformis made 62.5\% (MoyaElizondo et al., 2011). E. Moya-Elizondo with a group of scientists has expressed a hypothesis that this fungus might be one of the reasons for the darkening of stem base (Moya-Elizondo et al., 2015). On the other hand, the infection of switchgrass (Panicum virgatum) from Poaceae family with $P$. pontiformis 
has significantly increased the biomass of plants (Kleczewski et al., 2012). This suggests that the relationship between $P$. pontiformis and wheat should be studied in future.

The investigations have revealed the complexity of the problem of wheat crown rot, as this disease can be caused by different pathogens. Precise identification of it is necessary to understand the impact of agronomic practise. $O$. yallundae and $O$. acuformis have been found in Latvia (Bankina et al., 2016), but the percentage of these species is not known yet. $F$. culmorum and $F$. avenaceum were determined as the main Fusarium species in our previous investigations (Bankina et al., 2013); however, research must be continued because the conditions favourable for the development of particular species of Fusarium are still unclear.

\section{Conclusions}

1. The average incidence of stem crown rot was high (68\%), but the method of soil tillage did not influence the level of this disease in 2016.
2. The pre-crop of wheat significantly influenced the development of stem crown rot; continuous wheat sowings promoted development of this disease.

3. Different groups of fungi were isolated from wheat stem bases with disease symptoms. Overall, $56 \%$ of fungi were causal agents of wheat crown rot, $9 \%$ were different saprotrophic fungi, but $35 \%$ were identified as Phaeosphaeria pontiformis - an endophyte of wheat.

4. Oculimacula spp. and Fusarium spp. were found as the most important causal agents of crown rot, high occurrence of Microdochium spp. was recognized.

5. Further investigations are needed to identify the species of pathogens and to understand the ecological niches of other fungi.

\section{Acknowledgement}

The research was supported by the State research programme 'Agricultural Resources for Sustainable Production of Qualitative and Healthy Foods in Latvia', project No. 1 SOIL.

\section{References}

1. Bankina, B., Bimšteine, G., Roga, A., \& Fridmanis, D. (2016). Fusarium spp. and Oculimacula spp. the most important causal agents of wheat crown rot. In "Long-term agroecosystem sustainability: links between carbon sequestration in soil, food security and climate change", 4-6 October 2016 (pp. 15). Lithuania, Kaunas, International scientific conference AgroEco 2016.

2. Bankina, B., Bimšteine, G., Ruža, A., Priekule, I., Paura, L., Vaivade, I., \& Fridmanis, D. (2013). Winter wheat crown and root rot are affected bay soil tillage and crop rotation in Latvia. Acta Agriculturae Scandinavica, section B - Soil \& Plant Science. 63(8), 723 - 730. DOI: 10.1080/09064710.2013.861920.

3. Bankina, B., Ruža, A., Katamadze, M., Kreita, Dz., \& Paura, L. (2012). Snow Mould Development under Conditions of Central Part of Latvia. Proceedings of the Latvia University of Agriculture. 27(322), $1-5$. DOI: $10.2478 /$ v10236-012-0001-6.

4. Bateman, G.L., Gutteridge, R.J., Gherbawy, Y., \& Thomsett, M.A. (2007). Infection of stem bases and grains of winter wheat by Fusarium culmorum and F. graminearum and effects of tillage method and maize-stalk residues. Plant Pathology. 56, 604 - 615. DOI: 10.1111/j.1365-3059.2007.01577.x.

5. Crous, P.W., Groenewald, J.Z.E., \& Gams, W. (2003). Eyespot of cereals revisited: ITS phylogeny reveals new species relationships. European Journal of Plant Pathology. 109, 841 - 850. DOI: 10.1023/A:1026111030426.

6. CSP - Central Statistical Bureau (Centrālā Statistikas Pārvalde) (2016). Lauksaimniecības kultūru sējumu platība (tūkst. ha) (The crops sown area (thous. ha), Retrieved April 29, 2017, from: http://data.csb.gov.lv/ pxweb/lv/lauks/lauks_ikgad_03Augk/LA0150.px/?rxid=cdcb978c-22b0-416a-aacc-aa650d3e2ce0, (in Latvian).

7. Gala, D., Gorczyca, A., Oleksy, A., \& Kołodziejczyk, M. (2014). Stem-base disease in winter durum and common wheat cultivation in the years 2009-2011. Journal of Plant Protection Research. 54(1), 15 - 21. DOI: $10.2478 /$ jppr-2014-0003.

8. Janusauskaite, D., \& Ciuberkis, S. (2010). Effect of different soil tillage and organic fertilizers on winter triticale and spring barley stem base diseases. Crop Protection. 29 (8), 802 - 807. DOI: 10.1016/j. cropro.2010.04.002.

9. Jenkyn, J.F., Gutteridge, G.L., Bateman, G.L., \& Jalaluddin, M. (2010). Effects of crop drebis and cultivations on development of eyespot of wheat caused by Oculimacula spp. Annals of Applied Biology. 156(3), 387 - 399. DOI: 10.1111/j.1744-7348.2010.00396.x.

10. Jenkyn, J.F., Gutteridge, R.J., \& White, R.P. (2014). Effects of break crops, and of wheat volunteers growing in break crops ori n set-aside or conservation covers, all following crops of winter wheat, an the development of take-all (Gaeumannomyces graminis var. tritici) in succeeding crops of winter wheat. Annuals of Applieted Biology. 165(3), 340 - 363. DOI: 10.1111/aab.12139. 
11. Jonavičiene, A., Suproniene, S., \& Semaškiene, R. (2016). Microdochium nivale and M. majus as causative agents of seedling blight in spring cereals. Zemdirbyste-Agriculture. 103 (4), 363 - 368. DOI: 10.13080/za.2016.103.046.

12. Kleczewski, N.M., Bauer, J.T., Bever, J.D., Clay, K., \& Reynolds, H.L. (2012). A survey of endophytic fungi of switchgrass (Panicum virgatum) in the Midwest, and their putative roles in plant growth. Fungal ecology. 5, 521 - 529. DOI: 10.1016/j.funeco.2011.12.006.

13. Majchrzak, L., Sawinska, Z., Natywas, M., Skrzypczak, G., \& Głowicka-Wołoszyn, R. (2016). Impact of different tillage systems on soil dehydrogenase activity and spring wheat diseases. Journal of Agricultural Sciences and Technology.18, $1871-1881$.

14. Matušinsky, P., Mikolasova, R., Spitzer, T., \& Klem, K. (2008). Colonization of winter wheat bases by communities of pathogenic fungi. Cereal Research Communications. 36(1), 77 - 78. DOI: 10.1556/ CRC.36.2008.1.8

15. Matušinsky, P., Svačinová, I., Jonavičienè, A., \& Tvůružek, L. (2016). Long-term dynamics of causative agents of stem base diseases in winter wheat and reaction of Chech Oculimacula spp. and Microdochium spp. populations to prochloraz. European Journal of Plant Pathology. DOI: 10.1007/s10658-016-1082-8 (in Press).

16. Moya-Elizondo, E. (2013). Fusarium crown rot disease: biology, interactions, management and functions as possible sensor of global climate change. Ciencia e investigación agrarian. 40(2), 235 - 252. DOI: 10.4067/S0718-16202013000200001.

17. Moya-Elizondo, E., Arismendi, N., Castro, M.P., \& Doussoulin, H. (2015). Distribution and prevalence of crown rot pathogens affecting wheat crops in southern Chile. Chilean journal of agricultural research. 75(1), 78 - 84. DOI: 10.4067/S0718-58392015000100011.

18. Moya-Elizondo, E., Rew, L.J., Jacobsen, B.J., Hogg, A.C., \& Dyer, A.T. (2011). Distribution and Prevalence of Fusarium Crown Rot and Common Root Rot Pathogens of Wheat in Montana. Plant Diseases. 95, 1099 - 1108. DOI: 10.1094/PDIS-11-10-0795.

19. Polley, R.W., \& Turner, J.A. (1995). Surveys of stem base diseases and fusarium ear diseases in winter wheat in England, Wales and Scotland, 1989 - 1990. Annuals of Applied Biology. 126, 45 - 59. DOI: 10.1111/j.1744-7348.1995.tb05002.x.

20. Ren, R., Yan, X., \& Ray, R.V. (2015). Comparative aggressiveness of Microdochium nivale and M. majus and evaluation of screening methods for Fusarium seedling blight resistance in wheat cultivars. European Journal of Plant Pathology. 141(2), 141 - 281. DOI: 10.1007/s10658-014-0541-3.

21. Váňová, M., Matušinsky, P., Javůrek, M., \& Vach, M. (2011). Effect of soil tillage practices on severity of selected diseases on winter wheat (2011). Plant, Soil and Environment. 57, $245-250$.

22. Vujanovic, V., Mavragani, D., \& Hamel, C. (2012). Fungal communities associated with durum wheat production system: A characterization by growth stage, plant organ and preceding crop. Crop Protection. 37, 26 - 34. DOI: 10.1016/j.cropro.2012.02.006.

23. Weber, R., Kita, W., Pusz, W., \& Kieloch, R. (2016). The variability of the occurence of Fusarium culmorum in winter wheat grain in relation to climatic conditions and cultivation methods. Zemdirbyste-Agriculture. 103(1), 45 - 51. DOI: 10.13090/z-a.2016.103.006.

24. Wenda-Piesik, A., Lemaǹczyk, G., Paǹka, D., \& Piesik, D. (2016). Risk assessment posed by diseases in context of integrated management of wheat. Journal of Plant Diseases and Protection. 123 (1), 3 - 18. DOI: $10.1007 / \mathrm{s} 41348-016-0008-1$.

25. Winter, M., de Mol, F., \& Tiedemann, A. (2014). Cropping systems with maize and oilseed rape for energy production may reduce the risk of stem base diseases in wheat. Field Crop Research. 156, 249 - 257. DOI: 10.1016/j.fcr.2013.10.009. 